\title{
Numerical Study of Influence of Infill Walls on the Vertical Irregularity Limit of Turkish Seismic Code
}

\author{
Ugur Durak ${ }^{1}$, Kamil Aydin ${ }^{2}$ \\ ${ }^{1}$ Erciyes University \\ Department of Civil Eng., Faculty of Eng., 38039 Melikgazi, Kayseri, Turkey \\ ugurdurak@erciyes.edu.tr \\ ${ }^{2}$ Meliksah University \\ Department of Civil Eng., Faculty of Eng. and Arch., 38280 Talas, Kayseri, Turkey \\ kaydin@meliksah.edu.tr
}

\begin{abstract}
Weak/soft story irregularities are resulted from sudden changes of stiffness, strength and/or mass between adjacent stories. These irregularities introduce a soft zone into a structure where the damage initiates and concentrates, often leading to complete collapse. It is argued that masonry infill walls not constructed at ground floors of some commercial building create such a zone. To examine this phenomenon along stiffness irregularity conditions described in Turkish Seismic Code (2007), four reinforced concrete buildings are produced and tested in this study. The specimens consist of two reference bare frames, one frame with infill wall at the second story and one frame with infill walls at both stories. The frames and bricks used in the infill walls are scaled to 1/3 ratio. The frames are constructed in line with the code requirements. A quasi-static cyclic testing protocol is applied to simulate the earthquake loading while a constant axial loading is utilized to simulate the axial force present in column elements. The results of the experiments show that, at the early stages of time history of loading, the infill walls greatly contribute to the global stiffness of frame system. During this stage, the coefficient of stiffness irregularity indicates that only the frame with infill wall at the second story has a soft story. However, as the frame is further pushed/pulled into nonlinear region, the infill walls become no longer effective and frame behaves as a regular one. It is observed that, during this stage, the critical load carrying components of the frames assume no damage or jeopardized by infill walls. The experimental results of the study are also checked against those of the finite element modeling.
\end{abstract}

Keywords: Infill wall, stiffness irregularity, reinforced concrete frame, soft story.

\section{Introduction}

Many structures are designed with vertical irregularities due to functional, aesthetic or economic reasons. Vertical irregularities are resulted from sudden changes in stiffness, strength and/or mass between one or more adjacent stories [1]. These changes are attributed to variations in story height, setbacks, structural materials, structural system along the height of structure and unanticipated participation of non-structural components. It is well known that these irregularities constitute one of the main causes of failure during past earthquakes [2].

Simple analysis methods are available for designing regular structures. In the case of irregular structures, those simple methods are restricted by code regularity limits. For such structures, more advanced analysis methods are required to be utilized [3]. Few studies have been undertaken on the vertical irregularity effects. These studies can be grouped into those studies dealing with changes in lateral load carrying systems [2, 4], studies dealing with different story heights [5], studies dealing with structures having different floor masses $[6,7,8]$, studies dealing with setback structures $[9,10,11]$, studies dealing with variations in concrete and reinforcement used along the height of building [12, 13], and studies dealing with influences of nonstructural infill walls $[14,15,16,17]$.

Much attention has been given to infill walls resulting in horizontal or vertical irregularities. However, there appears to be no consensus on modeling, behavior or interaction between the infill wall and frame. Therefore, some international codes $[18,19]$ consider the role of infill walls in designing reinforced concrete frames, while others $[20,21]$ specifically recommend isolating infill walls from frames such that the stiffness of infill walls does not play any role in the overall stiffness of the frame [22]. In the latter case, the codes aims at preventing the problems associated with the brittle behavior and asymmetric placement of infill walls. There has been objection in the literature against the exclusion of wall components in the design process asserting that such an approach may conceal the potential detrimental effects of infill walls. 
Turkish Seismic Code 2007 - TSC 2007 [21] treats masonry infill walls as nonstructural elements in buildings. Although theirs effects are not included in the analysis, their weight is taken into account in the design process and their fractional area is considered while computing the weak story irregularity. There is evidence, however, due to recent studies $[16,23,17]$ that the presence of infill walls have significant influence on the seismic response of both analytical and real buildings. The study herein is carried out to examine this effect.

\section{Structural Models and Methodology}

Apart from the seismic dead load and fractional area effective in shear, TSC 2007 does not consider the positive contribution of infill walls to the initial stiffness of reinforced concrete frames. There are three types of irregularities in elevation in the code: weak story, soft story, and discontinuity of vertical structural elements. The code requires that a structure with a week story must be treated as irregular if the ratio of effective shear area of any story to that of story immediately above is less than 0.80 :

$$
\eta_{c i}=\frac{\left(\sum A_{e}\right)_{i}}{\left(\sum A_{e}\right)_{i+1}}<0.80
$$

Where $A_{e}$ is total area of columns, shear walls and infill walls effective in shear of the respective floor. The code describes the soft story irregularity as the ratio of the average story drift at any story to the average story drift at the story immediately above or below being greater than 2.0:

$$
\eta_{k i}=\frac{\left(\Delta_{i} / h_{i}\right)_{\mathrm{ave}}}{\left(\Delta_{i+1} / h_{i+1}\right)_{\mathrm{ave}}}>2.00
$$

where $\Delta_{i}$ is the drift and $h_{i}$ is the height of $i$ th story. There is an objection to the above definitions by the published research efforts on the grounds that these definitions do not appropriately reflect the positive or negative effects of infill walls on the global behavior of buildings. It is also claimed that many buildings collapsed due to soft/weak story mechanisms formed by infill walls at all floors but on the ground level of buildings. However, there is one reality that has been overlooked by these research studies that most of the collapsed buildings were not already designed in accordance with the code regulations. Therefore, it should be only fair to examine the influence of nonstructural infill walls on the lateral response of code-compliant building frames.

For the highlighted purpose, four $1 / 3$ scale RC specimens have been produced according to the requirements of TSC 2007 [21] and TS500 - Requirements for Design and Construction of Reinforced Concrete Structures [24]. The buildings comply with the entailed criteria of strong column-weak beam, minimum volumetric ratios and spacing of tie and longitudinal reinforcements in beams and columns, materials strengths of concrete and steel rods. The frames are also produced as not to have any irregularities represented in Eqs (1) and (2). Figure 1 shows the frame systems and Figure 2 the details of reinforcement and geometrical properties of beam and column elements. Several photos during the construction stage are also provided in Figure 3. Initial tests are performed to determine the expected strengths of concrete, reinforcement and bricks of infill walls. According to these tests, the concrete strength is C20/25, the mean yield strength of reinforcement is $460 \mathrm{MPa}$ and the ultimate strength is $590 \mathrm{MPa}$, and the mean compressive strength of brick units is 4.10 MPa.

The frame tests have been carried out at the Civil Engineering Laboratory of Erciyes University. The experiment setup consists of horizontal loading jack with a capacity of 60 tonf and vertical jack with a capacity of 100 tonf. Figure $4 a$ shows the hydraulic jack and its components of connection and Figure $4 \mathrm{~b}$ gives the overall view of the first specimen prior to testing. 

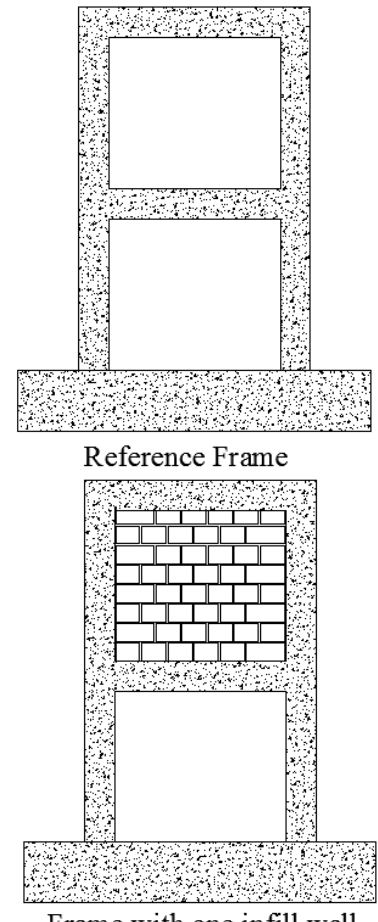

Frame with one infill wall
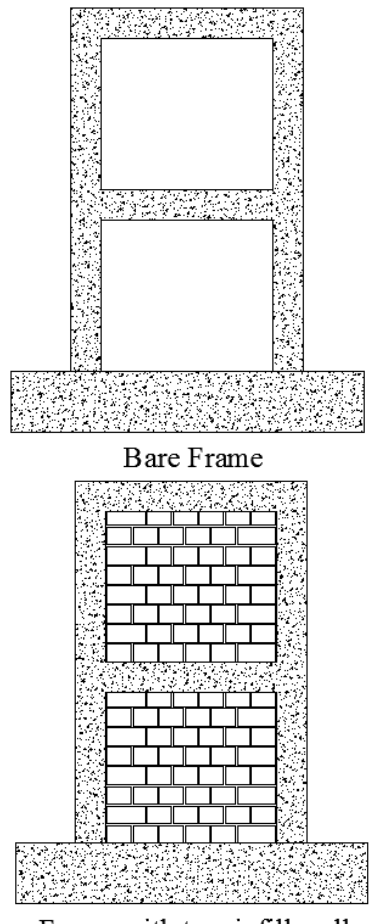

Frame with two infill walls

Fig. 1: Fabricated reinforced concrete specimens.

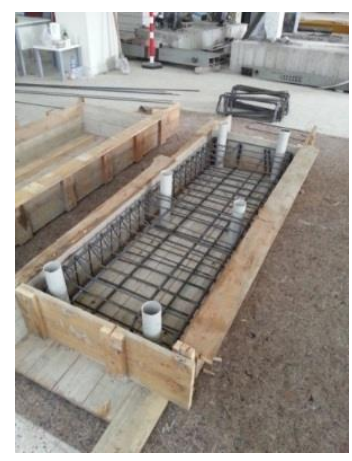

(a)

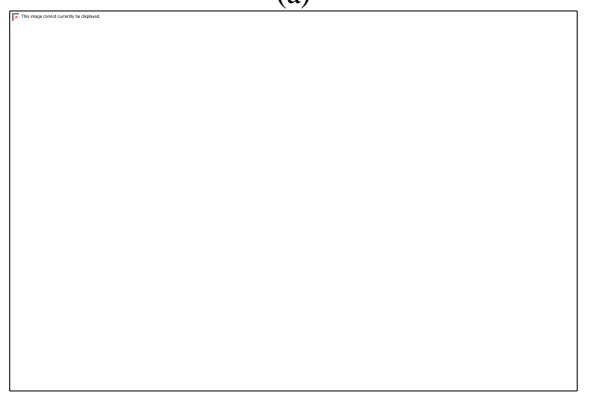

(c)

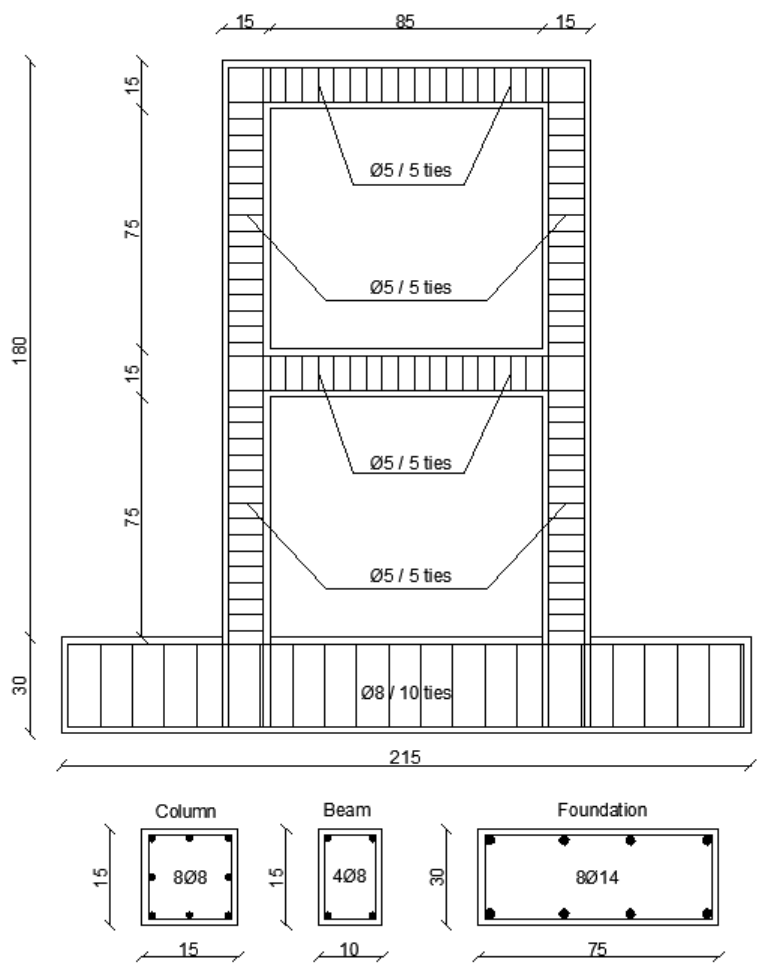

Fig. 2: Geometrical properties and reinforcement details of the frames (all dimensions are in $\mathrm{mm}$ ).

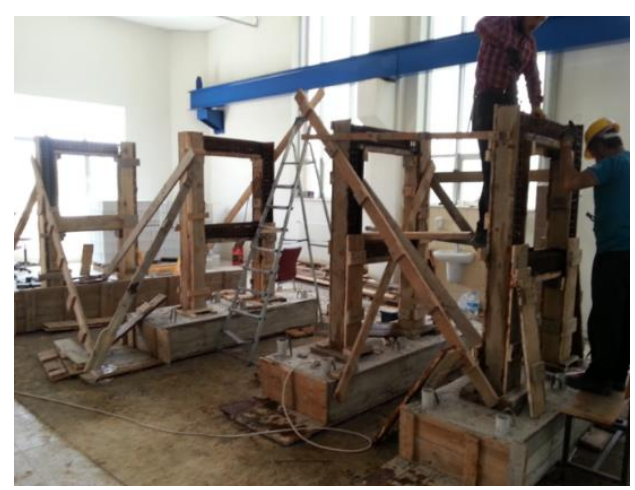

(b)

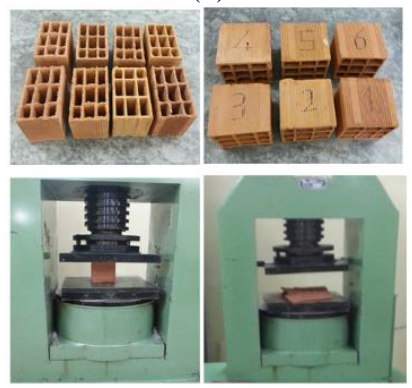

(d)

Fig. 3: (a) foundation formwork and its reinforcement, (b) frame formwork, (c) frames and infill walls, (d) compressive test of scaled brick units. 


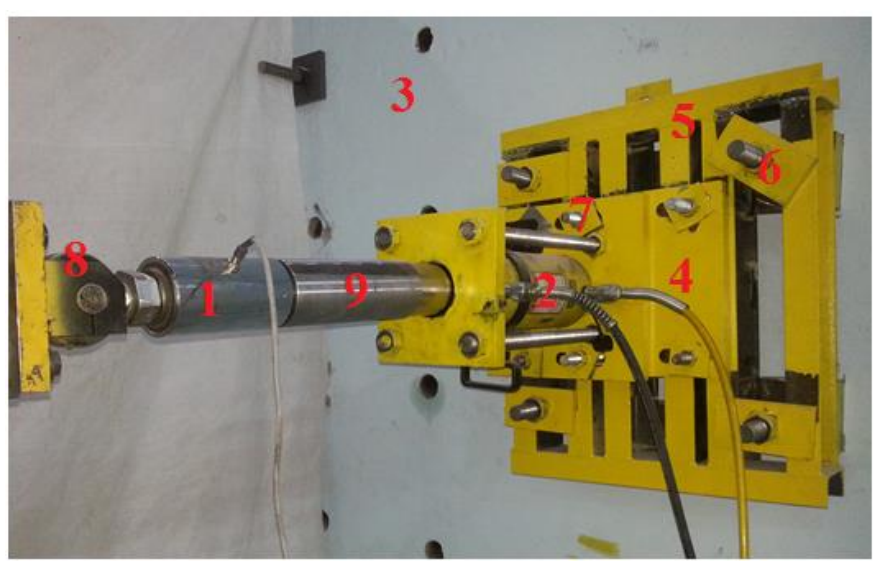

(a)

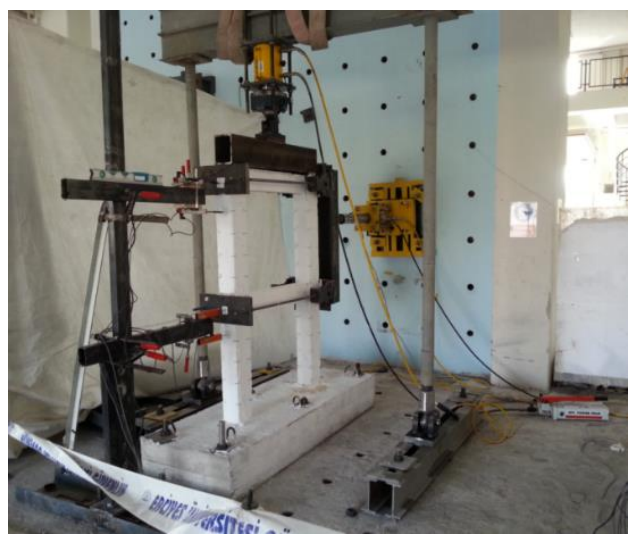

(b)

Fig. 4: (a) Horizontal loading jack and its components: 1-load cell, 2-hydraulic jack piston, 3-strong wall, 4- splice plate, 5-main connection rack, 6- main connection shaft, 7- sub-connection shaft, 8-horizontal loading pin, 9-extension member, (b) overall view of testing system.

\section{Results and Discussion}

Of the four specimens, the first one is utilized to test the load cells, components of the horizontal loading jack which had been newly constructed for the frames at hand, potentiometric displacement sensors and linear variable differential transformers (LVDTs). As for the loading protocol, the loading scheme provided by FEMA 461 [25] is assumed in the experiments. The magnitude of horizontal loading is increased at the each step with an increment of $1.5 \mathrm{kN}$ in the first experiment. At the end of this test, this quantity is deemed small and decided to be increased to $3 \mathrm{kN}$ for the other experiments. The loading protocol for the second specimen with no infill walls, for example, is given in Figure 5. The experiment is terminated at the $41^{\text {st }}$ cycle due to the exceedance of the capacity of LVDTs and loading units. The second story level is displaced $75.14 \mathrm{~mm}$ and the first story level by $38.18 \mathrm{~mm}$, which can be converted into story drift ratios of $4.11 \%$ and $4.24 \%$, respectively. The overall view of the specimen and some details of crack formation pertaining to beam-column joints at the end of the test are given in Figure 6. The incurring damages and measured displacement values indicate that the frame has behaved as a regular one. This is the expected response as the frame did not have any irregularities or infill walls.

In the following, the results of the other three specimens are given on a comparative basis. Figure 7 shows the graphs of lateral load versus top displacement for all the frames. It is observed that the frame with infill walls at both stories has the highest capacity followed by the frame with infill wall at the second story only and the frame with no infill walls. The presence of infill walls notably increases the initial global stiffness of the frames. It is noted the frames have the same strength once they are pushed/pulled to $100 \mathrm{~mm}$ displacement. At this stage, since the infill walls have already collapsed, it is deduced that the lateral load capacity is provided by the bare frames alone. A close inspection of the frame elements and joints indicates that no apparent damage has occurred at the mentioned locations.

The coefficient of stiffness irregularity as given in TSC2007 is computed at each load step and provided in Figure 8 for the second story and in Figure 9 for the first story level. It is observed from Figure 8 that no stiffness irregularity takes place at all levels of loading. Figure 9 shows that the frame with infill wall at the second story has stiffness irregularity (i.e., $\eta_{k i}>2.0$ ) at a load of $24.0 \mathrm{kN}$ during push and a load of $20.98 \mathrm{kN}$ during pull. However, when the load level increases, the irregularity disappears. Hence, this irregularity caused by the high initial stiffness of infill wall occurring at low levels of horizontal loading is of insignificance. From the plots, one can conclude that the presence of infill wall does not cause any detrimental effect in terms of weak/soft story mechanisms. Lastly, the tangent stiffnesses of the three frames are compared in Figure 10. It is seen from this figure that the infill walls greatly contribute to the global stiffness at the early stages of loading scheme. The initial stiffness of the frame with infill walls at both stories is 5.03 times higher than that of the bare frame and the stiffness of the frame with infill wall at the second story only is 4.55 times higher than that of the bare frame. Once the story drifts increase, the global stifnesses with infill walls start to decrease due to the cracks and crushing incurring in the bricks and mortar of infill walls. At a top displacement of approximately $40 \mathrm{~mm}$, all the frame buildings have the same global stiffness values. 


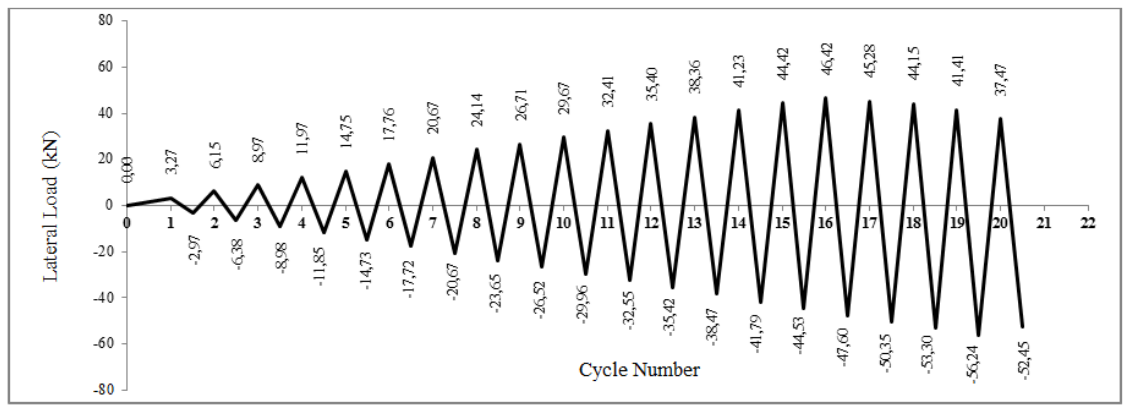

Fig. 5: Time history of horizontal loading for the second bare frame.

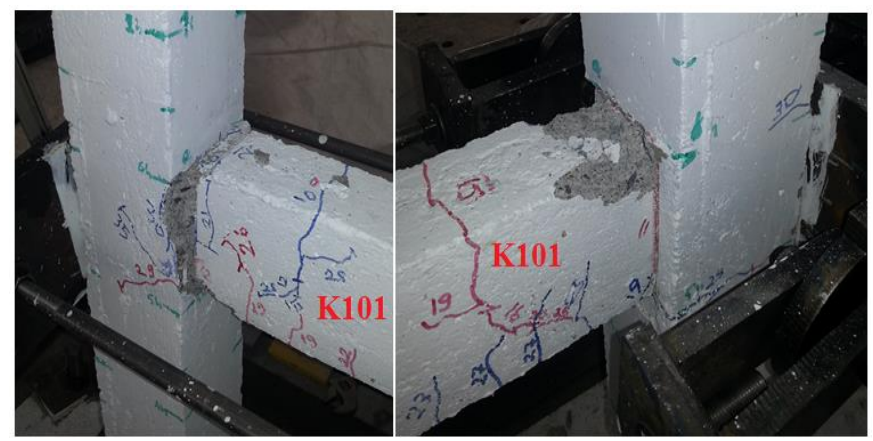

(a)
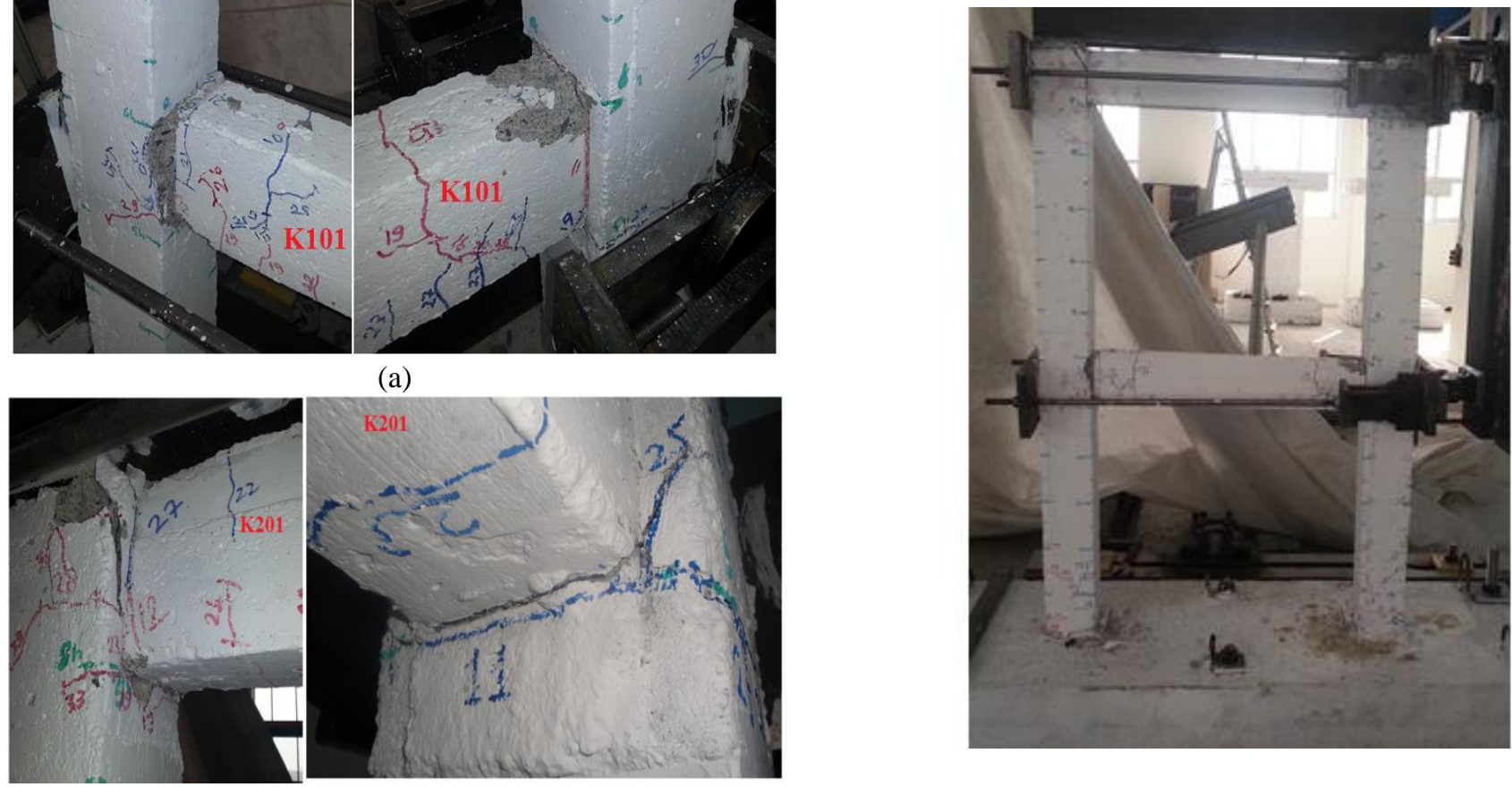

(b)

(c)

Fig. 6: (a), (b) Beam-column joints, (c) view of the frame at the end of the experiment.

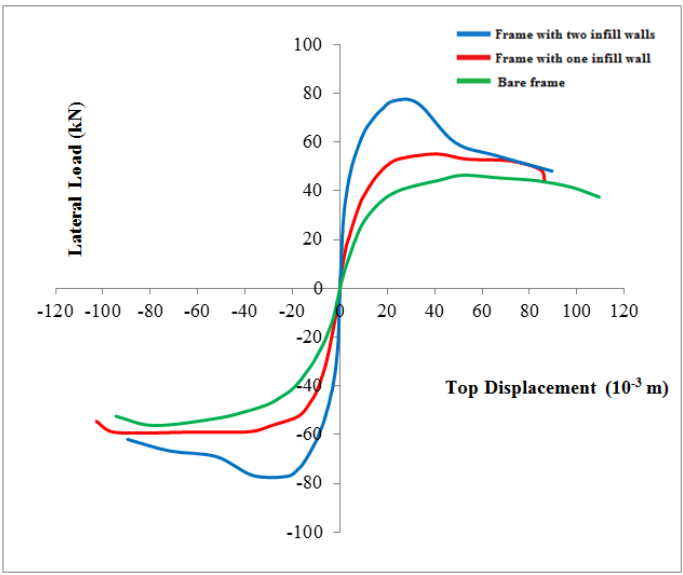

Fig. 7: Horizontal load vs. top displacement curves of all the three frames.

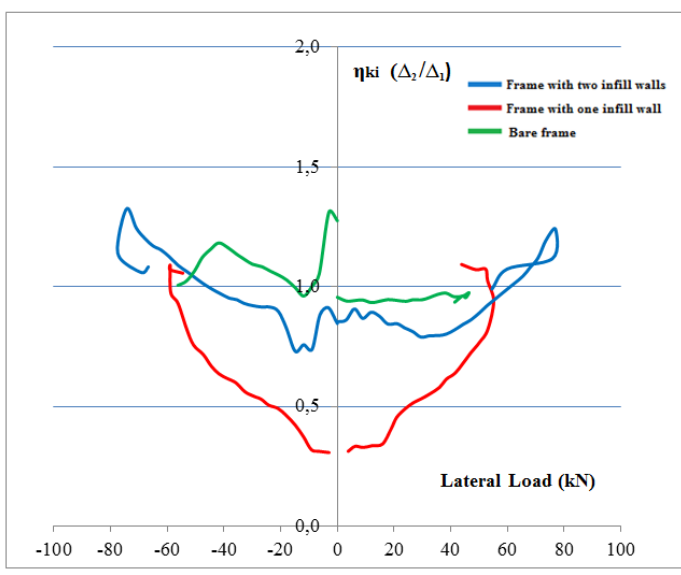

Fig. 8: Coefficient of stiffness irregularity a) for the second story, b) for the first story. 


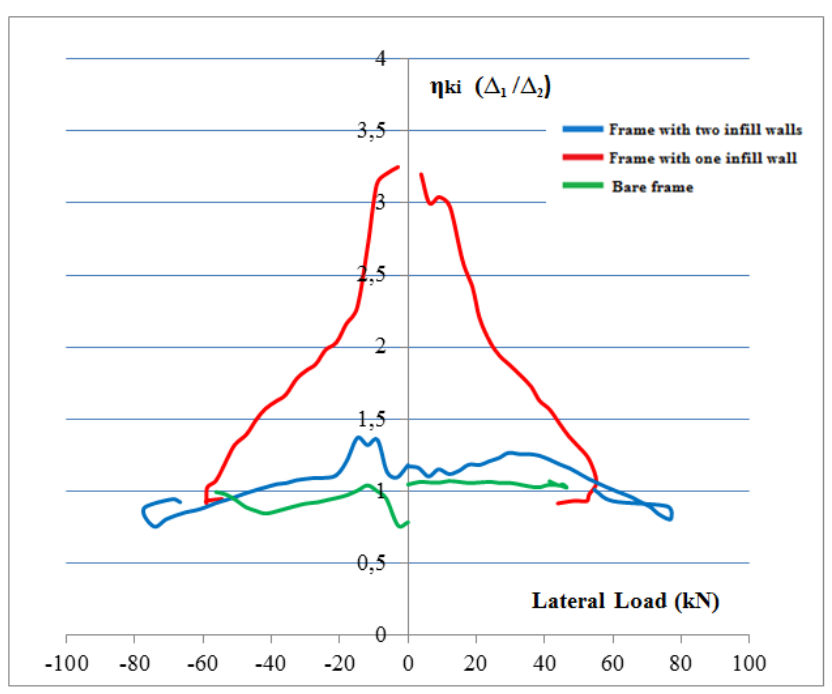

Fig. 9: Coefficient of stiffness irregularity for the first story.

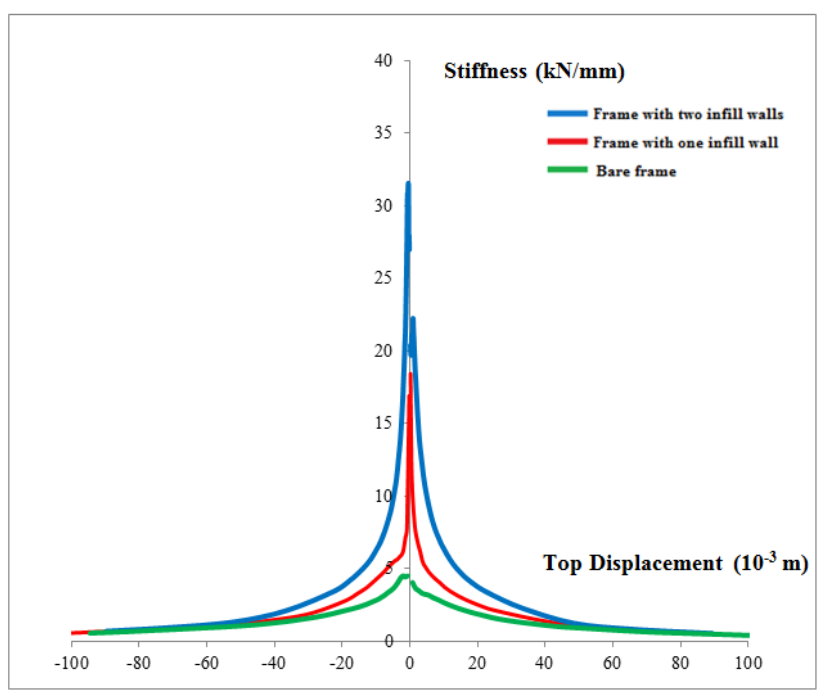

Fig. 10: Global stiffness vs. top displacement curves of all the three specimens.

\section{Conclusion}

Some published research articles assert that the infill walls that are not considered by TSC 2007 in the analysis of reinforced concrete buildings may cause vertical irregularity during horizontal earthquake shaking. To investigate this phenomenon experimental study is performed. Four one-third scale RC frames with and without infill walls are constructed compliant with the codes. The specimens are subjected to statically varying horizontal loading and constant vertical loading to simulate the axial loading in columns. At the end of experiments, it is found that the frame with infill walls at both stories has the highest lateral load capacity and the frame with no infill walls has the lowest. However, as the load intensity (or story drift ratio) increases towards the maximum permissible level, the capacities of all the frames get close to each other. Likewise, the frame having infill walls at both stories has the highest global stiffness during the early stages loading protocol. Once the infill walls get damaged, the stiffnesses of frame buildings become the same. This is also verified based on the comparison of coefficient of stiffness irregularity computed for all the frame systems.

The experimental results obtained in this work are verified by the numerical studies but due to lack of space, they are not provided herein. The results, however, should be verified by shake table tests.

\section{Acknowledgements}

This work was partially supported by Research Fund of Erciyes University, Kayseri with a project number of FYL2015-5898.

\section{References}

[1] J. Moehle, "Seismic response of vertically irregular structures," J. Struct. Eng. ASCE, vol. 110, no. 9, pp. 2002-2014, 1984.

[2] N. Kirac, M. Dogan, and H. Ozbasaran, "Failure of weak-story during earthquakes," Eng. Fail. Anal., vol. 18, no. 2, pp. 572-581, 2011.

[3] V. Sadashiva, G. A. MacRae, and B. L. Deam, "Building regularity provisions for seismic design of structures," in Proceedings of 14th European Conference on Earthquake Engineering (14ECEE), Ohrid, Macedonia, 2010.

[4] S. Salawdeh, "Displacement based design of vertically irregular frame-wall structures," Masters dissertation, ROSE School, Uni. of Pavia, Italy, 2009.

[5] A. Karaduman, "Dolgu duvarlı çerçevelerin yatay yükler altındaki davranışları üzerine deneysel bir çalışma (in Turkish)," Mühendislik Bilimleri Dergisi, Pamukkale Uni. Manisa, Turkey, vol. 11, no. 3, pp. 345-349, 2005. 
[6] A. A. K. Al-Ali and H. Krawinkler, "Effects of vertical irregularities on seismic behavior of building structures," Report No. 130, The John A. Blume Earthquake Engineering Center, Dept. of Civil and Env. Eng., Stanford University, Stanford, CA, 1998.

[7] K. Aydin, "Evaluation of Turkish seismic code for mass irregular buildings," Indian J. of Eng. Mater. Sci., vol. 14, no. 3, pp. 220-234, 2007.

[8] S. Varadharajan, V. K. Sehgal, and B. Saini, "Seismic behaviour of multistorey RC frames with vertical mass irregularities," Concrete Res. Lett., vol. 6, no. 1, pp. 21-39, 2015.

[9] B. M. Shahrooz and J. P. Moehle, "Seismic response and design of setback buildings," J. Struct. Eng. ASCE, vol. 116, no. 5, pp. 1423-1439, 1990.

[10] S. L. Wood, "Seismic response of R/C frames with irregular profiles," J. Struct. Eng. ASCE, vol. 118, no. 2, pp. 545566, 1992.

[11] C. J. Athanassiadou, "Seismic performance of R/C plane frames irregular in elevation," Eng. Struct., vol. 30, pp. 1250$1261,2008$.

[12] G. Magliulo, R. Ramasco, and R. Realfonzo, "Seismic vulnerability of R/C frames with strength irregularity in elevation," in Proceedings of the 13th World Conference on Earthquake Engineering, Vancouver, Canada, 2004.

[13] G. Magliulo and R. Ramasco, "Seismic performance of R/C frames with regular and irregular strength vertical distributions," in Proceedings of the 14th World Conference on Earthquake Engineering, Beijing, China, 2008.

[14] P. Negro and G. Verzeletti, "Effect of infills on the global behavior of R/C frames: Energy considerations from pseudodynamic tests," Earthquake Eng. Struc., vol. 25, no. 7, pp. 753-773, 1996.

[15] U. Ersoy, G. Ozcebe, T. Tankut, M. Türk, and O. Sonuvar, "Behavior of reinforced concrete infilled frames an experimental study," in Proceedings of the Second Japan Turkey Workshop on Earthquake Engineering, Istanbul, Turkey, 1998, pp. 292-308.

[16] S. Tezcan, A. Yazıcı A, Z. Özdemir, and A. Erkal, "Zayıf kat yumuşak kat düzensizliği (in Turkish)," in Proceedings of Altıncı Ulusal Deprem Mühendisliği Konferansı, Istanbul, Turkey, 2007.

[17] A. Yakut, B. Binici, I. O. Demirel, and G. Ozcebe, "Dolgu duvarların deprem davranışına etkisi (in Turkish)," in Proceedings of 2. Türkiye Deprem Mühendisliği ve Sismoloji Konferansl, Hatay, Turkey, 2013.

[18] Eurocode 8, prEN 1998-1, Design of Structures for Earthquake Resistance, Part 1: General Rules, Seismic Actions and Rules for Buildings, Final Draft, 2003.

[19] ICC, International Building Code. Falls Church, VA: International Code Council, 2003.

[20] SNZ. 2004. NZS 1170.5 Supp 1:2004, Structural Design Actions. Part 5: Earthquake actions - New Zealand Commentary. Standards New Zealand, Wellington, 2004.

[21] DBYBHY-07, Regulations for buildings to be constructed in earthquake prone areas, Turkish Seismic Design Code 2007, Ankara, Turkey, 2007.

[22] H. B. Kaushik, D. C. Rai and S. K. Jain, "Code approaches to seismic design of masonry infilled reinforced concrete frames: A state-of-the-art review," Earthq. Spectra, vol. 22, no. 4, pp. 961-983, 2006.

[23] M. Baran, "Dolgu duvarların betonarme çerçeveli yapıların davranışı üzerindeki etkilerinin incelenmesi (in Turkish)," Gazi Univ. Müh. Mim. Fak. Dergisi, vol. 27, no. 2, pp. 275-284, 2012.

[24] TS 500, Requirements for design and construction of reinforced concrete structures. Ankara, Turkey: Turkish Standards Institute (TSE), 2000.

[25] FEMA 461, Interim Testing Protocols for Determining the Seismic Performance Characteristics of Structural and Nonstructural Components (FEMA 461), Washington, DC, USA: Applied Technology Council for the Federal Emergency Management Agency, 2007. 